\title{
SMOKED AND FROZEN FISH CONSUMPTION AND MARKETING CHANNELS IN THE TAMALE METROPOLIS OF GHANA
}

\author{
Elliot H. Alhassan \\ Department of Fisheries \& Aquatic Resources Management, \\ University for Development Studies \\ Tamale-Ghana \\ Email: elliotalhassan@yahoo.com
}

Vivian F. Boateng

Department of Agribusiness Management \& Finance, University for Development Studies

Tamale-Ghana

Email: fiatusey2000@yahoo.com

and

Cecilia Ndaigo

Department of Fisheries \& Aquatic Resources Management, University for Development Studies,

Tamale-Ghana

Email: ceciliandaigo@yahoo.com

Doi:10.4314/gjds.v9i1.2

\begin{abstract}
Fish marketing has become an important trade in Ghana due to the increasing appreciation of the health benefits from consuming fish. This paper examines fish marketing and consumption in the Tamale Metropolis of Ghana with specific reference to consumer preferences. It discusses the results of a survey research that compares the marketing and consumption of smoked and frozen fish. One hundred and fifty respondents comprising smoked and frozen fish sellers and consumers were randomly selected and interviewed. Twenty-two smoked fish species were identified, out of which 12 were freshwater species while 10 were marine species. Eighty-six per cent (86\%) of consumers preferred smoked fish while 14\% preferred frozen fish. Herrings, horse mackerel and salmon were the most preferred fish. Consumer preferences were based on taste, affordability, availability and wholesomeness in soup and stew. The fishmongers indicated that they obtained their marine fishes from Kumasi (42\%), Techiman (30\%), Sunyani (19\%), Tema (5\%) and Takoradi (4\%) whiles freshwater fishes were obtained from Yeji/Makango (52\%), Buipe/Yapei (33\%), Nawuni/Botanga (9\%) and Techiman (6\%). The study showed that the marketing channel of frozen fish was simple while that of smoked fish was slightly more complex. Averagely, prices per kilogram of frozen or fresh (GH\$ 3.80) fishes were relatively cheaper compared to smoked (GHф 3.80) fish species.
\end{abstract}

KEY WORDS: Marketing, Consumers, Freshwater, Marine, Frozen Fish, Smoked Fish

\section{INTRODUCTION}

According to Clover (2005), fish is the best source of fat-free protein and vitamins and that, the omega-3-fatty acids in oily fish gives optimum brain function, reduces the danger of heart 
attacks, strokes and osteoporosis. Consuming fish has been found to slow down the ageing process while enabling people to lose weight because a fishy diet switches off the hunger hormone thus making people feel satisfied on smaller and more nutritious amounts of food. There is also a high demand for fish because it is an important source of cheap first class protein, providing essential amino acids (Paul and Southgate, 1978) and calcium, phosphorus, vitamin A and D (Brigette, Brigette, Corlein, 1994). Fish is also quicker to cook and more easily digested than meat (Mayhew \& Penny, 1988).

Yet, fish is an extremely perishable commodity, spoiling soon after death due to microbial actions, which result in disagreeable taste, smell and texture thereby reducing consumer acceptability (Garrow \& James, 1994). Maddison, Machell and Adams (1993) suggest the use of refrigeration as a means of preventing the fast rate of deterioration in fish. However, some bacteria such as Salmonella, which survive in refrigerators and brine, can only be destroyed by heating or smoking (Bender, 1982). In Ghana, various methods are used to preserve fish; namely, refrigeration, smoking, salting, drying and steaming. Fish refrigeration and smoking which is big business for consumers and marketers is the focus of this paper.

Fish smoking in Ghana is traditionally carried out by women in coastal towns and villages, along river banks and on the shores of Lake Volta. In most fishing communities, the main economic activity of women is fish processing (Essuman, 1992). Depending on the type of fish to be smoked, its uses and possible storage period, the smoking process can take the form of "wet" hot smoking or "dry" hot smoking. Both processes are carried out at temperatures above $80^{\circ} \mathrm{C}$, which are high enough to cook the fish (Clucas, 1982). Smoking also preserves fish by drying and depositing natural wood smoke chemicals like phenols and aldehydes, both of which have powerful bactericidal action and prevent the growth of other micro-organisms on the flesh of the fish (Garrow and James, 1994). Smoked fish is also tastier and provides longer shelf-life (Maddison et al. 1993).

The refrigeration of fish is another important means of preserving fish. It is practiced by both marketers and consumers. In the case of marketers such as importers, wholesalers and retailers who put raw or fresh fish in the markets, deep freeze them in order to extend their shelf life for distribution across the country and to small consumers such as households and big consumers such as hoteliers and processers. While hotel kitchens deep fry, grill and bake for their clients, processors such as market women smoke fish for retail. Fresh fish from local sources such as the sea, rivers, lakes and ponds as well as those from the import markets are frozen for distribution as raw fish.

The Tamale Metropolis, which is the focus of this paper, has in recent years been characterized by an increasing population that depends on various species of fish; smoked, frozen or fresh. The demand for fish in the Metropolis has been on the increase with daily influxes of various species into markets in Tamale (Opoku, 2003; Obodai, Mahammud, Obodai \& Opoku, 2009). The high demand for fish has resulted in a growth of a fish market that attracts largely women as retailers and/or wholesalers.

Although research on marketing has been done on smoked freshwater fishes in Ghana by Opoku (2003) and the effects of fuel wood on the quality of smoked freshwater fishes (Obodai et al. 2009), there has not been much documentation on consumption patterns and marketing channels, pricing and sources of fish especially with respect to the Tamale Metropolis. It is in view of this paucity of information that this research was carried out to determine the level of preference for smoked and frozen fish, outline the marketing channels of smoked and frozen fish and the price per kilogram of both smoked and frozen fish with a view to improving the marketing channels of processed fish in the Tamale Metropolis. 


\section{METHODS}

The study was conducted in the Tamale Metropolis of the Northern Region of Ghana. Geographically, the Metropolis lies between latitude $9^{0} 24^{\prime} \mathrm{N}$ and longitude $0^{0} 50^{\prime} \mathrm{W}$. There are three main market centres within the Tamale Metropolis namely Central, Aboabo and Lamashegu. These markets operate everyday with the designated market days being every six days. All the markets have well defined areas for the sale of smoked fish with a few individuals hawking within and around the markets. Fresh or frozen fish sellers own or use cold stores mainly within the central market with some dispersed especially along streets and a few found in the houses of individuals.

Fifty respondents each of smoked fish sellers, frozen fish sellers and consumers were randomly sampled from different parts of the Metropolis. Data collection was done mainly through the administration of semi-structured questionnaires to sellers and fish consumers in the Metropolis. The questionnaires were used to collect data on most preferred form of fish (frozen or smoked), prices per kilogram of smoked and frozen fishes, marketing channels and sources of fish, among others. The fish were identified by means of their external features, the use of fish identification books (Holden and Reed, 1972) and with the help of the sellers, especially for smoked fish. The data collected were analysed by means of descriptive statistics and the results presented in the form of percentages, graphs and percentages.

\section{RESULTS AND DISCUSSION}

This section of the paper focuses on the consumption and marketing channels of smoked and frozen fish in the Tamale Metropolis.

\section{The Fish Market and Marketers}

From the study, all the smoked fish sellers were females. This is in line with the findings of Essuman (1992) that men are not involved in the distribution and retail trade of cured fish. This is also in line with Abila (1998) who observed that the fish marketing and processing sector in Kenya is dominated by women while men specialize in fish harvesting. However, this research also revealed that some men (16\%) engage in the sale of frozen fish. Seventy-nine per cent $(79 \%)$ of fishmongers were migrants while $21 \%$ were natives.

\section{Fish Species and Sources}

Twenty-two smoked fish species were identified, out of which 12 (55\%) were freshwater species while 10 (45\%) were marine species. Most (55\%) of the fish species identified in the three markets; Central, Aboabo and Lamashegu, were freshwater species. This reason may be due to the closeness of the markets to the fish sources: Yeji/Makango and Buipe/Yapei.

However, the fishmongers indicated that they obtained marine fish from cold storage sources in Kumasi (42\%), Techiman (30\%), Sunyani (19\%), Tema (5\%) and Takoradi (4\%), all in southern Ghana. This may be because most of the fishmongers in the Metropolis are major retailers who prefer to buy their stocks from key wholesalers in the south in order to minimize operational costs. Also, for freshwater fish, the main sources identified were Yeji/Makango (52\%), Buipe/Yapei (33\%), Nawuni/Botanga (9\%) and Techiman (6\%). Compared to the results of an earlier work by Obodai and associates (2009), these authors recorded the same sources of freshwater fish in the Northern Region and only Yeji in the Brong Ahafo Region. The current results suggest that Techiman is also a source of freshwater fish into the Tamale Metropolis. This may be due to the large market center at Techiman, which attracts fish mongers from riverine communities within and even beyond the Brong Ahafo Region. 


\section{Marketing Channels}

The marketing channels of fish from the fisherman to the final consumer in the Tamale Metropolis for both smoked and frozen fish are illustrated in Figures $1 \mathbf{a} \& \mathbf{b}$ below. The most prominent marketing channel for smoked fish is that between fishermen, fishmongers and consumers whereas that for frozen fish is between the wholesalers, retailers and consumers. The channel of marketing of smoked fish in the Tamale Metropolis was slightly more complex than that of frozen fish. This was probably because they have to deal with a chain of operatives from the source through various market outlets before reaching the consumer. This confirms the findings of Chapman and Hall (1994) that, the route by which sea foods reach the consumer may be direct or highly complex with a variety of exchanges. Most individual consumers, restaurants, chop bars, and other food vendors purchase frozen fish directly from the nearby wholesalers. This was perhaps due to their relatively cheaper price compared to that of retailers. This also confirms the findings of Barwuah (1998) that wholesale cold stores sell at lower prices to attract more customers.
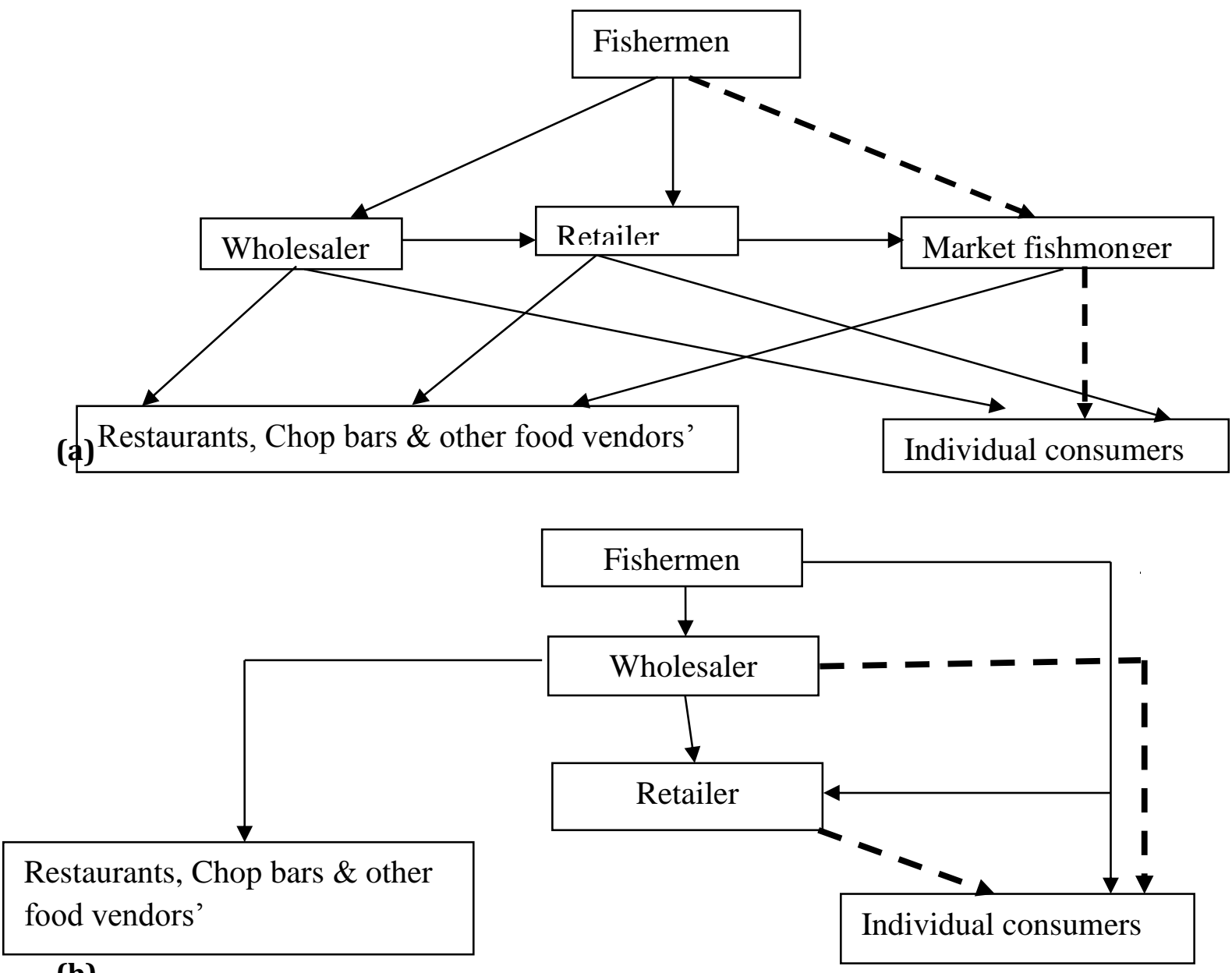

(b)

Figure 1: Channels of smoked (a) and frozen (b) fish marketing in the Tamale Metropolis

Note: The highlighted broken lines denote the major marketing channels that exist between the smoked and frozen fishes respectively in the Tamale Metropolis 


\section{Consumer Preferences}

\section{Preference by Type}

All the identified fish species were preserved either by smoking or freezing. However, there tended to be a higher preference (86\%) for smoked fish compared to frozen fish (14\%). The high demand for smoked fish in the Tamale Metropolis was attracted to flavour, taste and product, as found by Pyke (1981) and the extended shelf-life as found by Maddison and associates (1993). The results also confirm the findings of Essuman (1992) who reported that smoking is the main method of preserving fish and the product is readily available in many markets throughout the country.

Cost was an important factor in consumer preference by fish type. Herrings (Clupea harengus) were the most preferred fish species whether smoked or frozen by the consumers, probably due to low costs while frozen Tilapia (Oreochromis niloticus) and Redfish (Sebastes marinus) were the least preferred due to high costs. Mudfish/Catfish (Clarias garienpinus) were the most preferred freshwater species due to their low prices. The preference for the less expensive fish could also be due to the fact that Tamale Metropolis is located in one of the poorest regions in Ghana where consumers were unable to purchase the most expensive fish in the markets.

\section{Preference by Taste}

Taste preference of fish species by consumers is shown in Figures 2a \& b respectively. Herrings (Clupea harengus), Horse mackerel (Rastrelliger kanagurta) and Salmon (Salmo salar) were the most preferred, smoked or frozen. Electric fish (Malapterurus electricus) was the least preferred among the smoked fishes whereas redfish (Sebastes marinus) and tilapia (Oreochromis niloticus) were the least preferred frozen fishes. Preferences were based on taste/flavour, affordability, availability and wholesomeness in soup and stew.

Consumers attributed their choice of smoked fish to the fact that they had nice flavour, good taste, remained whole in soups and stews and could be stored for longer periods compared to frozen fish. This agrees with the findings of Clucas (1982) that smoking prolongs the shelf life and enhances the flavour. The results also showed that smoking of the freshwater species was mostly $(70 \%)$ done at the source by wholesalers whiles the smoking of marine species was mainly $(85 \%)$ done by retailers.

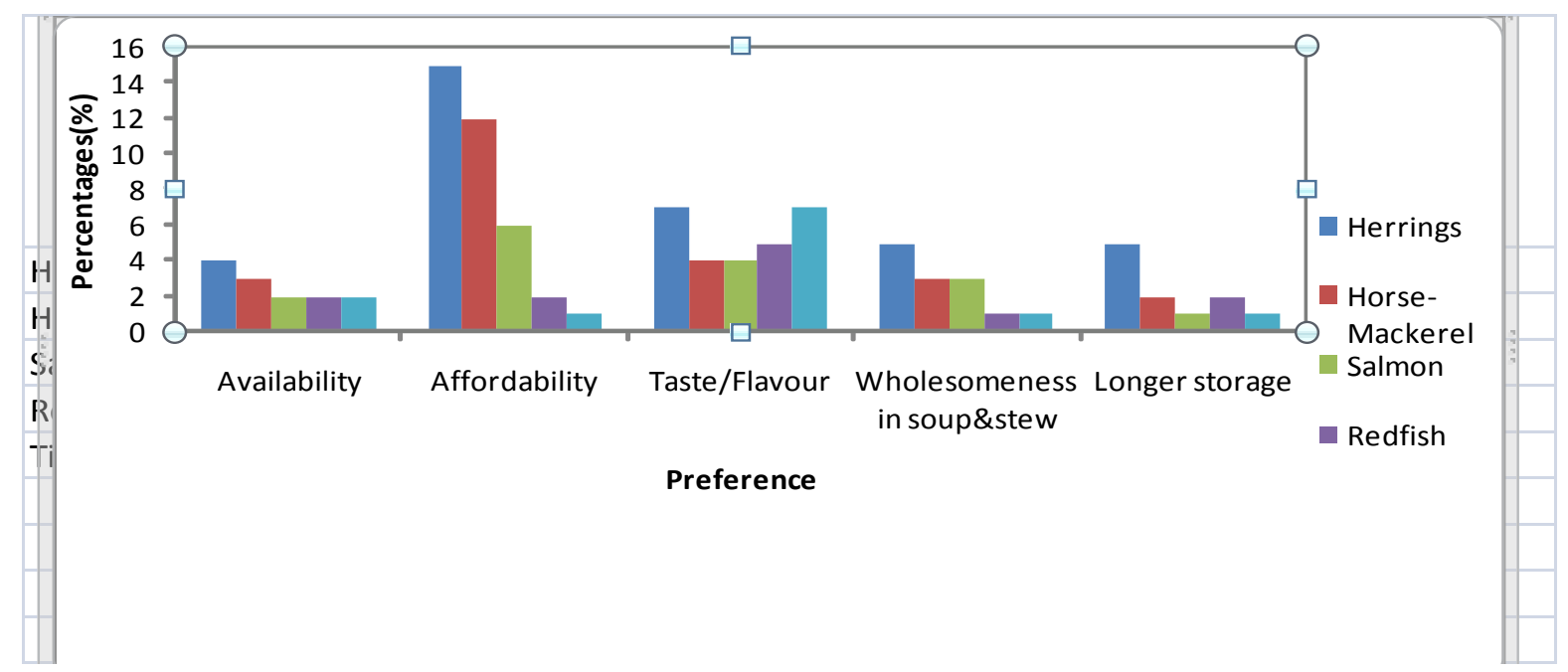

Figure 2a: Consumer preference of frozen fish 


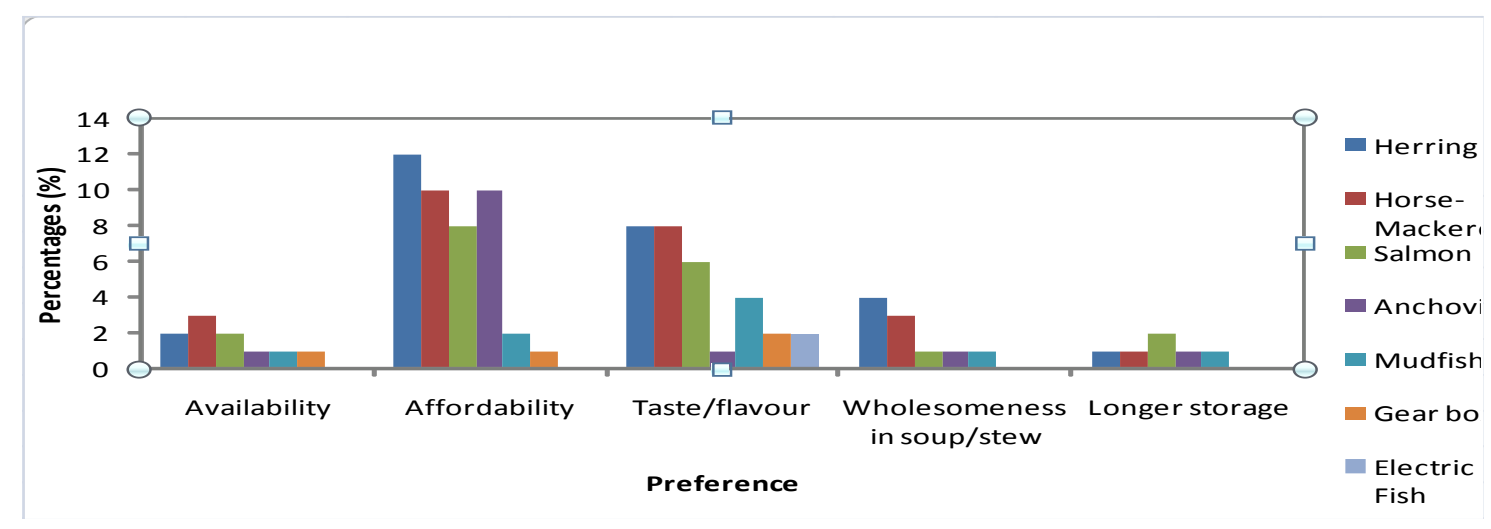

Figure 2b: Consumer preference of smoked fish

\section{Pricing}

Smoked fish species were priced higher per kilogram compared to frozen fish species (Table 1). Herrings (Clupea harengus) was the lowest priced per kilogram for both smoked $(\$ 5.10 / \mathrm{kg})$ and the frozen $(\$ 2.20 / \mathrm{kg})$ fish whereas the electric fish (Malapterurus electricus) $(\$ 13.10 / \mathrm{kg})$ attracted the highest price per kilogram for the smoked fishes in the Tamale Metropolis. The smoked marine fish were more expensive than frozen fish probably due to the additional cost incurred in using fuel wood and labour. While on the other hand smoked freshwater species generally attracted higher prices per kilogram than smoked marine species. This could be due to the extra effort that is required in smoking them compared to their marine counterparts. The high demand for freshwater fish species was due to their taste and the long marketing channel it passes through to the final consumer prompting fish mongers to inflate their prices.

Table 1: Average prices per kilogram of smoked and frozen fishes in the Tamale Metropolis (January - March, 2010). Scientific names in brackets.

\section{Type}

Herrings

(Clupea harengus)

Horse-mackerel

(Rastrelliger kanagurta)

Salmon

(Salmo salar)

Redfish

(Sebastes marinus)

Tuna

(Katsuwonus pelamis)

Tilapia

(Oreochromis niloticus)

Anchovies

(Engraulis encrasicolis)

Catfish

(Heterobranchus bidorsalis)

Mudfish

(Clarias garienpinus)

Gearbox

(Chrysichtys auratus)

Electric fish

(Malapterurus electricus)

\section{Price per Kg GHc}

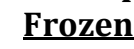

2.20

5.10

Smoked

2.70

5.80

3.80

6.90

5.50

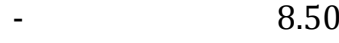

5.50

11.30

-

9.60

10.10

1020

13.10

Source: Field Survey, 2010 


\section{CONCLUSION}

The study revealed that most consumers in the Tamale Metropolis preferred smoked fish to frozen fish. This could be due to the fact that smoked fish was perceived to taste better and of longer shelf-life. The significant contribution of the sources of freshwater fish species from the Northern and Brong-Ahafo regions to the Tamale Metropolis is indicative of self-sufficiency in freshwater fish production in these areas. The marketing channel for frozen fish was simple while that of smoked was more complex, making the smoked fishes more expensive because the products had to pass through many hands before getting to the final consumer. Overall, consumer preferences and marketing trends were consistent with existing data elsewhere as reflected in the analyses above.

\section{REFERENCES}

Abila, R. O. (1998). "The patterns and trends of marketing and consumption of the fish of Lake Victoria (Kenya Waters)." African Journal of Tropical Hydrobiology and Fisheries. 8: 45-50.

Barwuah, S. (1998). "Market survey of fishes in Sunyani." Diploma Thesis submitted to the Institute of Renewable Natural Resources, Kwame Nkrumah University of Science and Technology, Kumasi (Unpublished).

Bender, D.A. (1982). Dictionary of Nutrition and Food Technology. $5^{\text {th }}$ edition. Cambridge, UK. CRC Press.

Brigitte, M. B.; Brigitte, V. B. and Corlein, H. (1994). Preservation of Fish and Meat. Netherlands. Agrodok Series No. 12.

Chapman, H. and Hall, E. (1994). Fisheries Processing Biotechnological Application. London, UK: Chapman and Hall Publication

Clover, C. ( 2005). The End of the Line: How Overfishing is Changing the World and What we can Eat. London, UK: Edbury Press.

Clucas, I. J. (1982). Fish handling, preservation and processing in the tropics. Part 2 Report of the Tropical Development and Research Institute. Rome, Italy (unpublished).

Essuman, K. M. (1992). Fermented fish in Africa. A study on processing, marketing and consumption. FAO Fisheries Technical Paper. No. 329. Rome, Italy(unpublished).

Garrow, J. S. and James, W. P. T. (1994). Human Nutrition and Dietetics. London, UK: Churchill Livingstone.

Holden, M. and Reed, W. (1972). West African Freshwater Fish. London, UK: Longman Group.

Maddison, A.; Machell, K. and Adams, L. (1993). Fish processing: Food Cycle Technology Source books. London, UK: International Technology Publications.

Mayhew, S. and Penny, A. (1988). Tropical and sub-Tropical Foods. London, UK: MacMillan.

Obodai, E. A., Muhammad, B. A., Obodai, G. A. and Opoku, E. (2009). "Effects of fuelwood on the quality of smoked freshwater fish species sold in the Tamale Central Market, Northern Region, Ghana." Ethiopian Journal of Environmental Studies and Management, 2(2): 27 - 35. 
Opoku, E. (2003). Survey of smoked freshwater fishes in Tamale Central market. B.Sc.

Dissertation submitted to the Department of Renewable Natural Resources, University for Development Studies. Tamale, Ghana (unpublished).

Paul, W. and Southgate, L. (1978). Fish and Meat Consumption in the Tropics. London, UK: MacMillan.

Pyke, M. (1981). Success in Nutrition. London, UK: John Murray Ltd. 